\title{
Public investment, competitiveness and development: a study into Brazilian tourism destinations
}

\author{
Daniel Pires Vieira1 \\ Valmir Emil Hoffmann' \\ Anete Alberton ${ }^{2}$ \\ 1 Universidade de Brasília / Programa de Pós-Graduação em Administração, Brasília / DF — Brazil \\ 2 Universidade do Vale do Itajaí / Programa de Pós-Graduação em Administração, Itajaí / SC — Brazil
}

\begin{abstract}
This paper analyzes the efficiency of federal government funding for destination competitiveness and the relationship among destination competitiveness enhancement and local development. Destination competitiveness models provide the theoretical background. The research is exploratory and descriptive. We mapped the investments from Brazilian Ministry of Tourism in 65 destinations. Destination Competitiveness was measured with information from the Brazilian Competitiveness Model. Data were analyzed with data envelopment analysis and multiple regression analysis. Study findings demonstrate that competitiveness enhancement does not depend on the amount of funding, but on its strategic application according to destination development stage. Besides, competitiveness dimensions Marketing, Monitoring, and Cooperation are major drivers for local development.
\end{abstract}

Keywords: destination management; competitiveness; tourism; efficiency.

\section{Investimentos públicos, competitividade e desenvolvimento: um estudo em destinos turísticos brasileiros}

Este artigo analisa a eficiência do financiamento público federal para a competitividade de destinos turísticos e a relação competitividade e desenvolvimento local. Modelos de competitividade de destinos turísticos fornecem o arcabouço teórico. A pesquisa é exploratória e descritiva. Foram mapeados os investimentos do Ministério do Turismo em 65 destinos brasileiros. A competitividade dos destinos foi medida com informações do Modelo Brasileiro de Competitividade. Os dados foram analisados com análise envoltória de dados e análise de regressão múltipla. Os resultados do estudo demonstram que o aumento da competitividade não depende do montante do financiamento, mas da sua aplicação estratégica de acordo com o estágio de desenvolvimento do destino. Além disso, as dimensões de competitividade marketing, monitoramento e cooperação se mostraram como os principais impulsionadores do desenvolvimento.

Palavras-chave: gestão de destinos; competitividade; turismo; eficiência.

\section{Inversiones públicas, competitividad y desarrollo: un estudio en destinaciones turísticas brasileñas}

Este artículo analiza la eficiencia del financiamiento público federal para la competitividad de destinos turísticos y la relación competitividad y desarrollo local. Los modelos de competitividad de destinos turísticos proporcionan el marco teórico. La investigación es exploratoria y descriptiva. Se identificaron las inversiones del Ministerio de Turismo en 65 destinos brasileños. La competitividad de los destinos fue medida con informaciones del Modelo Brasileño de Competitividad. Los datos fueron analizados con análisis envolvente de datos y análisis de regresión múltiple. Los resultados del estudio demuestran que el aumento de la competitividad no depende del monto de la financiación, sino de su aplicación estratégica de acuerdo con la etapa de desarrollo del destino. Además, las dimensiones de competitividad marketing, monitoreo y cooperación se mostraron como los principales impulsores del desarrollo.

Palabras clave: gestión de destinos; competitividad; turismo; eficiencia. 


\section{INTRODUCTION}

Tourism has been acknowledged as an economic activity with positive potential effects on economic diversification. It has played an important tool for income and job generation as an important impact on poverty alleviation (Lage and Milone, 2001; Heath, 2003; González and Ruiz, 2006; Sinclair and Stabler, 2009). These potential benefits, however, are achieved through the destination performance in the market, which makes destination competitiveness an issue not only for the academy, but also for governments. One might notice that destination competitiveness is not an end in itself, but rather an intermediate goal towards the economic development and social well-being in tourism destinations (Crouch and Ritchie, 1999; Dwyer and Kim, 2003; Rivero and Caldera, 2004).

The growing attention of the academy on the theme can be verified by the vast number of recent scientific papers written on the subject (Castrillón et al., 2011). Different models devoted to assess destination competitiveness have been developed over the last years. Practical perspective, several actions have been undertaken. Trimarchi (2004) described the cooperation stablished among local government and tourism enterprises in order to develop cultural tourism in Siena - Italy. André (2004) indicates the importance of strategic planning with the participation of both public and private organizations for a better marketing position of tourism destinations. Similar aspects are described for tourism growth in Barcelona, where public and private organizations created a consortium (Bonet, 2004). The importance of the tourism competitiveness may also be observed through the increasing number of DMOs (Destination Management/Marketing Organizations) created. Besides branding and positioning destinations (Pike and Page, 2014), DMO's aim is to create an atmosphere where the visitors can experience a range of activities meanwhile being aware of the social and economic well-being of the residents (Bornhorst, Ritchie and Sheehan, 2010).

The importance of destination competitiveness in Brazil may be evidenced by two aspects. The first is a model dedicated to assess the competitiveness of 65 tourist destinations. The Brazilian Competitiveness Model (BCM), developed by the Brazilian Ministry of Tourism (MTur) in association with the Getulio Vargas Foundation (FGV) and The Brazilian Service to Micro \& Small Enterprises (Sebrae), assesses the competitiveness of 65 Brazilian key destinations. The second aspect is the public investments made by the Ministry of Tourism over the last years. The MTur, differently from other DMO's, has a broad focus of action. Its investments include: general and tourism infrastructure, work force qualification, promotional and marketing actions, among others.

These characteristics present in Brazil represent an opportunity to address some open issues. Since Governments seek interest in destination competitiveness, it is worth questioning whether governmental actions are effective in improving competitiveness. The BCM evaluates competitiveness from thirteen aspects (also called dimensions) and is used as an instrument for evaluation of tourism public policies (Barbosa, Oliveira and Rezende, 2010). Identifying which aspects enhance destination competitiveness is necessary to establish appropriate strategies for a sustainable tourism development (González and Ruiz, 2006; Barbosa, Oliveira and Rezende, 2010). Analyzing the influence of public investments on destination competitiveness allows us to identify how competitiveness can be improved. Notwithstanding, under academic lenses, it might also be useful to understand how the enhancement of competitiveness affects local socioeconomic development. Besides, public policy evaluation is a

Brazilian JoURnal Of PUblic administration ｜ Rio de Janeiro 52(5):899-917, Sept. - Oct. 2018 
developing research field in Brazil (Trevisan and van Bellen, 2008; Ramos and Schabbach, 2012; Crumpton et al., 2016).

The present study aims to contribute to these debates. Thus, this paper objective is twofold: (i) analyze the efficiency of federal government funding for competitiveness development; (ii) analyze competitiveness enhancement effects on economic and social development. In order to accomplish the proposed objective, the paper proceeds as follows. The second section presents the theoretical framework that will guide the subsequent analyzes. The third section describes the research method. The fourth section presents the results of the analysis while the fifth section presents the conclusions.

\section{THEORETICAL BACKGROUND}

The concept of competitive advantage has evolved towards a systemic perspective. At a first moment, competitiveness analysis focused on the firm's performance as a consequence of the industry characteristics, as described by Porter (1986) and other author of the structure-conduct-performance (SCP) paradigm. Afterwards, competitiveness was analyzed as a result of a firm-specific attributes, characteristics and resources as designed by the Resource Based View (RBV) (Barney, 1991). Then the concept of competitiveness advances towards a more comprehensive analysis, which includes characteristics of the firm's social environment. In this sense, competitiveness involves not only the organizations directly linked to the productive process, but also those sets of relationships that can boost synergies and promote competitiveness and development for the companies as well as for the region (Esser et al., 1996).

Destination competitiveness models follow this systemic approach. Tourism destinations are geographical regions that offer a whole series of integrated tourist products and services that are commercialized and consumed by tourists under the common brand of the destination (Buhalis, 2000; Hassan, 2000; Pavlovich, 2003; Michael, 2007). The services offered to tourists in a destination are composed by a set of complex, heterogeneous and complementary economic activities (Denicolai, Cioccarelli and Zucchella, 2010; Ritchie and Crouch, 2010; Czernek and Czaron, 2016). These characteristics unable the analysis of destination competitiveness based solely on the perspective of a single economic activity. In spite of these arguments, the successful development of a tourist destination needs to comprise the social actors who suffer the direct and indirect impacts of tourism development and ought to benefit from the activity (Crouch and Ritchie, 1999; Hassan, 2000; Dwyer and Kim, 2003; Heath, 2003). The study of destination competitiveness requires a comprehensive viewpoint that takes into account all the different factors that directly or indirectly influence the performance of the destination.

Despite the extensive literature on destination competitiveness, there seems to be no generally accepted definition of a competitive advantage for tourism destinations (Crouch and Ritchie, 1999; Barbosa, Oliveira and Rezende, 2010). Cvelbar and collaborators (2016) explain this lack of definition due to the complex association of the theme with economic and non-economic features. Some authors describe destination competitiveness as the ability of a destination to create new products that increase the value of their resources while maintaining their market position in relation to their competitors (Hassan, 2000). Others researchers define it as the destination's attractiveness or the destination's capacity to provide unique experiences for its visitors (Crouch and Ritchie, 1999; Dwyer and Kim,

BRAZILIAN JOURnal OF PUblic administration | Rio de Janeiro 52(5):899-917, Sept. - Oct. 2018 
2003). According to Ritchie and Crouch (2010), destination competitiveness relates to the capacity of effectively deploying endowment resources in order to generate growth and development to the tourism sector. More recently, Cvelbar and collaborators (2016) defined destination competitiveness as the total tourism contribution to GDP per tourism employee. Similarly, Nuñez (2010) assessed the competitiveness of Brazilian cities based on indicators such as average salary and employment level.

Despite the lack of a widely-accepted definition, there seems to be an agreement on the concept that destination competitiveness' ultimate goal is to provide better living conditions for local residents (Crouch and Ritchie, 1999; Hassan, 2000; Dwyer and Kim, 2003; Heath, 2003; Rivero and Caldera, 2004; Ritchie and Crouch, 2010). Cvelbar and collaborators (2016) highlight that, even though some tourism researchers understand that destination competitiveness is an intermediate goal towards socioeconomic prosperity, little or no empirical evidence has been presented in order to corroborate this argument.

Given the absence of a common definition, the study of destination competitiveness may be characterized by the application of several theoretical and methodological approaches regarding the competitiveness construct and the way it is measured. Although the concept of competitiveness is relative and multidimensional (Crouch and Ritchie, 1999; Rivero and Caldera, 2004), one can note numerous of partially focused studies that deal with only some of the aspects that influence competitiveness (Taberner, 2007; Barbosa, Oliveira and Rezende, 2010; Miki, Gândara and Muñoz, 2012).

Some comprehensive models have been developed over the last years. The earliest and eventually most influential contributions on destination competitiveness' study are the Calgary Model, proposed by Couch and Ritchie (1999), and the Integrative Model, proposed by Dwyer and Kim (2003). The Calgary Model is based on a systemic approach and associates the concept of tourism destination competitiveness with its ability to contribute towards the local economy and to increase the quality of life for the local population. Following Crouch and Ritchie (1999), Dwyer and Kim (2003) proposed a model to evaluate tourism destination competitiveness that contains several of the variables and dimensions identified at the Calgary Model. The Integrative Model (Dwyer and Kim, 2003) enhances destination competitiveness explanation by establishing a clearer relationship among dimensions and identifying a set of indicators that allow competitiveness assessment and comparison.

Heath (2003) presented a very similar contribution to the previous models for competitiveness assessment. Heath (2003) conceives destination competitiveness as a house, in which the foundations are composed by the key attractors (created or endowed) and the structure is composed by aspects that enable their appropriate exploitation in order to generate an adequate experience for the visitors and development for local population (Heath, 2003). Although Heath (2003) contributes to the organization and identification of the relationship between the different dimensions that influence competitiveness, its model does not set variables or indicators that allow measuring the competitiveness hindering the evaluation and comparison of tourist destinations. A limitation common to these first destination competitiveness models is the absence of feasible indicators for empirical application that would make it possible to compare different destinations.

Gooroochurn and Sugiyarto (2004) created the Competitiveness Monitor that assesses tourism competitiveness of over two hundred countries using data from international organizations. Similarly, the World Economic Forum (WEF) evaluates tourism competitiveness of different countries through 
the Travel and Tourism Competitiveness Report (WEF, 2015). These models provide a set of indicators that allow competitiveness evaluation and comparison among different countries, overcoming one of the limitations of previous models. Both models maintain systemic characteristics and advance beyond the limitations of the models proposed by Crouch and Ritchie (1999) and Dwyer and Kim (2003). Notwithstanding, depending on destination's characteristics some indicators ought to be more relevant than others. There is no set of competitiveness indicators appropriate to all destinations (Dwyer and Kim, 2003; Rivero and Caldera, 2004). The practical application of these models is also open to criticism. Tourism is an economic activity territorially localized (Buhalis, 2000; Pavlovich, 2003; Michael, 2007) and the use of countries as unit of analysis makes it difficult to understand the different household realities. Another difference of the initial models is a greater focus on business generation and the absence of an explicit acknowledgment of local population as the ultimate beneficiary of tourism development.

Following the example of these latest models and aiming at guiding policies for tourism development, MTur carries out, since 2008, a research in order to determine the competitiveness level of 65 national key destinations. So as to establish the dimensions for the analysis of destination competitiveness, the study defined competitiveness as: "the growing capacity for generating business in the economic activities connected with the tourism sector, in a sustainable way, providing the tourist with a positive experience" (Brazilian Ministry of Tourism, Sebrae, Fundação Getulio Vargas, 2008:32). To put this concept in effect, the Brazilian Competitiveness Model evaluate competitiveness from five macro-dimensions subdivided in thirteen dimensions that assess destination competitiveness from primary and secondary data (Barbosa, Oliveira and Rezende, 2010).

According to Crouch (2011), the models developed for the study of destination competitiveness reached a maturity level in which all the relevant characteristics for competitiveness' assessment were identified, however it is also worth discussing which of these attributes are indeed decisive for competitiveness. In order to contribute to this discussion Cvelbar and collaborators (2016) analyzed several databases and proposed to evaluate destination competitiveness based on six destination competitiveness factors: (i) Business Environment; (ii) Macro-Environment; (iii) General Infrastructure; (iv) Endowed Resources; (v) Tourism Infrastructure; and (vi) Destination Management. The results showed that the determinant destination factors vary according to the countries' economic development.

Competitiveness models stress the role of destination's resources for competitiveness enhancement. These resources are usually divided in three groups: (i) Endowed Resources; (ii) Created Resources; and (iii) Support Resources. Endowed Resources are natural, cultural or heritage resources and constitute the main aspects of a destination appeal and are key for visitor's motivation (Crouch and Ritchie, 1999; Hassan, 2000; Dwyer and Kim, 2003; Cvelbar et al., 2016). Created Resources or Tourism Infrastructure are complementary resources that compose the experience offered to the visitors, including tourism services and touristic infrastructure (Dwyer and Kim, 2003; Cvelbar et al., 2016). Support Resources are created resources that do not compose the set of attractors or services of a destination, but enable the exploitation of the other resources, including transport and general infrastructure (Crouch and Ritchie, 1999; Ritchie and Crouch, 2010).

It is interesting to notice that, markedly in the early models, natural and cultural resources, even though recognized as important bases for tourism attractiveness, are not capable of directly influencing 
destination competitiveness, since they depend on other resources and dimensions that might improve or decline their potential. Endowed resources are usually associated to comparative advantages and must be properly deployed and explored in order to achieve destination competitiveness and local development (Crouch and Ritchie, 1999; Hassan, 2000; Cracolici and Nijkamp, 2008; Wilde e Cox, 2008), which stress the role played by the tourism infrastructure, the created resources and the destination management.

Destination management is directly related to the ability of deploying and exploring destination resources. Destination management are those activities devoted to improve destination attractor and strengthen the quality and effectiveness of created and support resources (Crouch and Ritchie, 1999; Dwyer and Kim, 2003; Ritchie and Crouch, 2010). Among other activities, destination management includes destination promotion and marketing, gather and use of information, monitoring and evaluation, and destination planning (Dwyer and Kim, 2003). In addition to these activities, Ritchie and Crouch (2010) also highlight the importance of human resource development to provide a positive service experience and address the needs of tourism and hospitality industry. The results of Cvelbar and collaborators (2016) indicate that destination management is an important factor for both developed and developing countries' competitiveness.

Tourism is an economic activity characterized by clusters of small and medium-sized companies that provide complementary services (Buhalis, 2000; Pavlovich, 2003; Michael, 2007; Mazaro and Varzin, 2008). Several studies highlight the need for productive integration and inter-organizational relations to generate better products and services and, as a consequence, to achieve better results for both enterprises and the territory (Hassan, 2000; Dwyer and Kim, 2003; Pavlovich, 2003; Ritchie and Crouch, 2010; Denicolai, Cioccarelli and Zucchella, 2010; Maggioni, Maroz and Mauri 2014; Czernek and Czaron, 2016). Productive integration and the promotion of cooperation are aspects related to destination management that influence competitiveness.

From a touristic perspective, a destination does not achieve success only due to tourism activities (Enright and Newton, 2004). Manifold environmental characteristics, most of them not under control of firms or tourism organizations, influence a destination competitiveness. Demand and situational conditions may be characterized as forces outside destinations' control that may constrain the strategic options and ultimately may enhance or reduce destination competitiveness (Crouch and Ritchie, 1999; Dwyer and Kim, 2003). On the other hand, microenvironmental conditions are made up of organizations, influences, and forces that lie within the destination's immediate arena, which include the tourism business sector, suppliers, public agencies, destination stakeholders and other competing tourism markets (Crouch and Ritchie, 1999).

One may notice that the range of issues (at least partially) under regard of government organizations is considerable and include among others: planning and coordinating activities between destination management organizations (Crouch and Ritchie, 1999; Dwyer and Kim, 2003); environmental management and protection (Hassan, 2000; Dwyer and Kim, 2003; Mazaro and Varzin, 2008); tourism and general infrastructure (Gooroochurn and Sugiyarto, 2004; Rivero and Caldera, 2004), destination promotion and marketing (Crouch and Ritchie, 1999; Buhalis, 2000; Dwyer and Kim, 2003) and manpower programs (Dwyer and Kim, 2003). All these issues are necessary conditions for destination competitiveness and ultimately destination development. Provided that competitiveness 
is an intermediate goal towards local development (Crouch and Ritchie, 1999; Dwyer and Kim, 2003; Rivero and Caldera, 2004), from a public policy perspective, competitiveness might be considered as an outcome indicator, since it signposts to what extent the government interventions have achieved their objective (Trevisan and van Bellen, 2008; Ramos and Schabbach, 2012). As a consequence, competitiveness impact ought to be measured through local development indicators.

\section{METHOD}

The present research is characterized as exploratory and descriptive with the application of quantitative techniques. The data analyzed was collected from 65 tourism destinations selected by MTur (box 1). These destinations are spread all over the country and since 2008 are subject of a research from MTur intending to evaluate and monitor their competitiveness by applying the BCM (Brazilian Ministry of Tourism, Sebrae and Fundação Getulio Vargas, 2008, 2010).

\section{BOX $1 \quad$ LIST OF TOURISTIC DESTINATIONS}

\begin{tabular}{|c|c|c|c|c|}
\hline Destination — State & Destination - State & Destination - State & Destination - State & Destination - State \\
\hline Alto Paraíso (G0) & Brasília (DF) & Gramado (RS) & Natal (RN) & Recife (PE) \\
\hline Angra dos Reis (RJ) & Cáceres (MT) & Ilhabela )SP) & Nova Olinda (CE) & Rio Branco (AC) \\
\hline Aracaju (SE) & Caldas Novas (G0) & Ipojuca (PE) & Ouro Preto (MG) & Rio de Janeiro (RJ) \\
\hline Aracati (CE) & Campo Grande (MS) & Bonito (MS) & Palmas (T0) & Salvador (BA) \\
\hline Búzios (RJ) & Corumbá (MS) & João Pessoa (PB) & Paranaguá (PR) & Santarém (PA) \\
\hline Balneário Camboriú (SC) & Cuiabá (MT) & Lençóis (BA) & Paraty (RJ) & São Joaquim (SC) \\
\hline Barcelos (AM) & Curitiba (PR) & Macapá (AP) & Parintins (AM) & São Luís (MA) \\
\hline Barreirinhas (MA) & Diamantina (MG) & Maceió (AL) & Parnaíba (Pl) & São Paulo (SP) \\
\hline F. de Noronha (PE) & Belém (PA) & Manaus (AM) & Petrópolis (RJ) & Boa Vista (RR) \\
\hline Belo Horizonte (MG) & Florianópolis (SC) & Maragogi (AL) & Pirenópolis (G0) & Teresina (PI) \\
\hline Bento Gonçalves (RS) & Fortaleza (CE) & Maraú (BA) & Porto Alegre (RS) & Tibau do Sul (RN) \\
\hline S. Raimundo Nonato 9PI) & Foz do Iguaçu (PR) & Mata de S. João (BA) & Porto Seguro (BA) & Tiradentes (MG) \\
\hline Jijoca de Jericoacoara (CE) & Goiânia (G0) & Mateiros (TO) & Porto Velho (R0) & Vitória (ES) \\
\hline
\end{tabular}

Source: BCM (Brazilian Ministry of Tourism, Sebrae, Fundação Getulio Vargas, 2008:34).

The analysis used secondary data collected from governmental databanks. For each destination were collected sets of information about: public investment, tourism competitiveness and local development. Data on investment were collected from the Brazilian Federal Government Transparency website (www.portaltransparencia.gov.br). The study considered only the funding from the MTur applied directly in the 65 destinations. Taking into account the time necessary for the investments 
to be implemented and the time necessary to generate the results intended, the study considered the investments as the total amount invested from 2007 to 2009. The investments were classified in five different categories: (i) Infrastructure and Basic Services (Infra); (ii) Training \& Qualification (T\&Q); (iii) Marketing and Publicity (M\&P); (iv) Destination Management (DM); and (v) Routes \& Segments (R\&S). Box 2 shows the proposed system of classification with examples of interventions. There was no available data about private investments or the amount invested by municipal or state governments. The absence of these information is a limitation of the study.

\section{BOX 2}

\section{CLASSIFICATION OF INVESTMENTS}

\begin{tabular}{|c|c|}
\hline Classification & Examples of Intervention \\
\hline Infrastructure and Basic Services — Infra & $\begin{array}{l}\text { Water supply, sanitation, electrical energy, transport and } \\
\text { urbanization. }\end{array}$ \\
\hline Training \& Qualification - T\&Q & $\begin{array}{l}\text { Capacity building and professional training for business leaders } \\
\text { and professionals working in the tourism sector. }\end{array}$ \\
\hline Marketing \& Publicity — M\&P & $\begin{array}{l}\text { Marketing, publicity and other activities for the commercial } \\
\text { promotion of tourism destinations. }\end{array}$ \\
\hline Destination Management — DM & $\begin{array}{l}\text { Planning, research and other actions designed to strengthen } \\
\text { institutional capacity for tourism destinations management. }\end{array}$ \\
\hline Routes \& Segments - R\&S & $\begin{array}{l}\text { Investments for the development of new tourism routes and } \\
\text { diversification of tourism segments. }\end{array}$ \\
\hline
\end{tabular}

Source: Elaborated by the authors.

Data on destination competitiveness was gathered from the results of the Brazilian Competitiveness Model (BCM) carried out by the Ministry of Tourism. The BCM provides a competitiveness index and thirteen competitiveness dimensions measured on a scale from 0 to 100 points. The Study classifies the destinations under five headings: Competitive Deficiency (0 to 20 points); Inadequate (21 to 40 points); Satisfactory (41 to 60 points); Adequate (61 to 80 points); and Superior (81 to 100 points) (Brazilian Ministry of Tourism, Sebrae, Fundação Getulio Vargas, 2008, 2010). The analysis used the competitiveness dimensions and considered the percental growth rate between the years 2008 and 2010 for comparison and evaluation of destination competitiveness enhancement.

The variable number of jobs on accommodation services were used to evaluate local socioeconomic development. The tourism economy comprises several economic activities, but accommodation services are the economic activity more directly associated with the tourism development (Brazilian Institute of Geography and Statistics - IBGE, 2008). From the perspective of public policy, tourism development is justified by the potential benefits generated for the local population. Among these benefits, we highlight the generation of jobs. Dwyer and Kim (2003) consider both the absolute number of employments and its growth rate as indicators of tourism contribution to local economy. Employment was also used as explanatory variable in empirical studies (Cvelbar et al., 2016; Nuñez, 
2010). Data on accommodation services employment were gathered from the Annual List of Social Information (Rais), a Brazilian Ministry of Labor and Employment's database. The variable about local development was considered as the percental growth rate, having the year 2008 as baseline and 2010 as the final evaluation year.

The analysis was divided into two parts. The first part studies MTur's funding influence on competitiveness development. The analysis employed Data Envelopment Analysis (DEA) technique. DEA is a nonparametric analysis that considers multiple input and output measures in evaluating relative efficiency (Barros, 2005; Medina, Gómez e Marrero, 2012). It is important to emphasize that the public policies implemented by the MTur are decentralized. So that, destinations request funding from MTur. Therefore, for the DEA analysis, each destination was considered as a decision-making unit (DMU). The volume of financial resources funded by MTur was considered as the inputs and the development of competitiveness (measured as the variation of the indicators of each dimension) the outputs. Considering that the investments are not completely under control of the DMUs, an input-oriented model was favored. Additionally, considering that the destinations under analysis have different sizes and different initial levels of competitiveness, a variable returns of scale (BCC) model was preferred. The DEA analysis was undertaken using the Integrated System for Decision Support software (Ângulo Meza et al., 2004).

The second part of the paper analyzes the influence of competitiveness enhancement on local development. Multiple regression was used as analyses technique. Following the arguments that competitiveness indicators may vary according to destination segments (Dwyer and Kim, 2003; Rivero and Caldera, 2004), the effects of competitiveness were controlled by demand characteristics and the destinations' main attractions. In this sense, dummy variables were created in order to classify the 65 destinations as business destinations, sun and sand destinations, natural and cultural destinations. Multiple Regression Analysis were performed with the Software Statistical Package for Social Sciences (SPSS). The following sections present the results achieved.

\section{EFFICIENT PATTERNS OF PUBLIC INVESTMENTS FOR COMPETITIVENESS ENHANCEMENT}

A central aspect of public policy evaluation is the efficiency of public expenditure (Trevisan and van Bellen, 2008; Ramos and Schabbach, 2012; Crumpton et al. 2016). The DEA intended to identify which destinations are efficient applying funding from MTur (inputs) and increasing competitiveness (outputs). DEA results identified 13 efficient destinations. It may be observed that the average value invested in efficient destinations during the period analyzed was USD 2,657,475,00, ${ }^{1} 45.15 \%$ less than the average value invested in all the 65 destinations (USD 4.845.666,00). The competitiveness index of these destinations suffered an average increase of 11.4 points. Taking into account the amount invested in efficient destinations, it is observed that approximately five hundred thousand US Dollars were invested for each incremental competitiveness point obtained. DEA results enable us to identify the pattern of federal expenditure in efficient destinations.

${ }^{1}$ Exchange Rate USD 1 = R \$ 2,04 (Real Brazil/BRL). Reference Date: December 31th, 2012. Source: Brazilian Central Bank. 
Considering the efficient destinations and the classification proposed by the MTur model (2008), only two efficient destinations (Ipojuca and Cuiabá) evolved to a superior category. Most of the efficient destinations were classified in an intermediate category (Satisfactory). Only capital cities were included in the superior intermediary ratings (Adequate). Only one destination (Ipojuca) was initially classified as Inadequate and, during the period analyzed, rose to reach a Satisfactory rating (see table 1).

\section{TABLE 1 A SCALE OF COMPETITIVENESS INVESTMENTS AND EVOLUTION}

\begin{tabular}{|c|c|c|c|c|c|c|c|c|}
\hline \multirow[t]{2}{*}{ Destination } & \multirow{2}{*}{$\begin{array}{l}\text { Technical } \\
\text { Efficiency }\end{array}$} & \multicolumn{5}{|c|}{$\%$ Invested } & \multicolumn{2}{|c|}{$\begin{array}{l}\text { Competitiveness } \\
\text { Classification } 1\end{array}$} \\
\hline & & Infra & $T \& Q$ & M\&P & DM & $R \& S$ & 2008 & 2010 \\
\hline Angra dos Reis & 0.949 & 72.22 & 27.78 & 0 & 0 & 0 & S & S \\
\hline Bonito & 0.916 & 100 & 0 & 0 & 0 & 0 & S & S \\
\hline Caldas Novas & 0.566 & 90.11 & 0 & 9.89 & 0 & 0 & S & S \\
\hline Cuiabá* & 0.716 & 37.99 & 0 & 61.08 & 0.93 & 0 & S & A \\
\hline Curitiba* & 0.773 & 20.35 & 37.88 & 32.12 & 8.45 & 1.19 & A & A \\
\hline Florianópolis* & 0.768 & 27.82 & 8.05 & 58.28 & 2.57 & 3.28 & A & A \\
\hline Іројuca & 0.892 & 100 & 0 & 0 & 0 & 0 & 1 & S \\
\hline Macapá* & 0.587 & 45.33 & 0 & 5.39 & 49.28 & 0 & S & S \\
\hline Palmas* & 0.849 & 65.99 & 17.44 & 16.57 & 0 & 0 & S & S \\
\hline Paranaguá & 0.873 & 93.55 & 0 & 6.45 & 0 & 0 & S & S \\
\hline Porto Alegre* & 0.907 & 54.90 & 9.71 & 30.75 & 4.64 & 0 & A & A \\
\hline Rio Branco* & 0.822 & 97.58 & 0 & 2.42 & 0 & 0 & S & S \\
\hline Tibau do Sul & 0.977 & 92.08 & 0 & 7.92 & 0 & 0 & S & S \\
\hline \multicolumn{2}{|c|}{ Mean Efficient Destinations } & 69.07 & 7.75 & 17.76 & 5.07 & 0.34 & - & - \\
\hline \multicolumn{2}{|c|}{ Mean Inefficient Destinations } & 64.46 & 5.53 & 22.10 & 1.46 & 0.32 & - & - \\
\hline
\end{tabular}

Source: Elaborated by the authors.

${ }^{1}$ Legend: S - Satisfactory; A — Adequate; I — Inadequate. Scale BCM (MTur, 2008: 35).

* State capital cities.

All efficient destinations received investments in Infrastructure (Infra). This result seems to corroborate WEF's (2015) perspective that Brazil needs to improve its infrastructure to achieve a better competitive position. One might notice that investments in infrastructure are relatively smaller in capital destinations. Capital cities are usually better served of general infrastructure and therefore less dependent of these kinds of investments. 
Marketing and Publicity (M\&P) investments were the second most common category for efficient destinations (present in $84.6 \%$ of the cases) followed by Destination Management (DM) and Training \& Qualification (T\&Q) investments (present in 38.5\% of the destinations). Routes and Segments (R\&S) investments were present in only $15.4 \%$ of the cases. Most of the efficient destinations received investments in two or more categories. These findings support the arguments that destination competitiveness is multidimensional (Crouch and Ritchie, 1999), since destination competitiveness enhancement demands investments in several areas.

Notwithstanding, Adequate destinations received investments in more categories, but the relative amount invested in infrastructure was inferior when compared to destinations classified under other categories. Only one efficient destination, initially classified as Inadequate (Ipojuca), received investments exclusively in infrastructure and rose to achieve a Satisfactory rating. The smaller amount invested in infrastructure may be explained by the fact that all destinations classified as Adequate are capital cities, which usually are economic centers of the state with an existing basic infrastructure. Based on these findings, one might infer that infrastructure has greater relevance for competitiveness in destinations at early stages of development. As the destinations develop and become more competitive, investments in infrastructure becomes less necessary and gradually are substituted by other investments aiming at qualifying and improving tourism products.

Ritchie and Crouch (2010) highlight that the condition and extent of a destination's general infrastructure are among the most important supporting factors for destination competitiveness. This perspective finds support in Cvelbar and collaborators (2016). The authors demonstrated that general infrastructure has influence on competitiveness of both developed and developing countries. For developed countries infrastructure was considered the main competitiveness driver (Cvelbar et al., 2016). Even though it was not possible to differentiate the amount invested specifically in tourism infrastructure and in general infrastructure, the results found differ from those of Cvelbar and collaborators (2016), since the infrastructure is more important for destinations in the early stages of development.

Training and Qualification are recognized by Crouch and Ritchie (1999) and Dwyer and Kim (2003) as support resources to tourist attractions. Except for Curitiba, which received $37.88 \%$ of investments in this category, the remaining destinations classified at Adequate rating received around $10 \%$ of the total amount invested in Training and Qualification. Capital cities can offer a wider selection of capacity building and professional training courses, since a greater number of technical training centers and institutions are usually available, which makes investments in these activities a lower priority for local governments.

Investments in Marketing and Promotion were relatively high in the four destinations (Cuiabá, Curitiba, Florianopolis and Porto Alegre) rated as Adequate (always over 30\% of total investment) in 2010. Cuiabá in particular, whose competitiveness rose from Satisfactory to Adequate, received $61 \%$ of its investments in this category. Marketing and promotional activities are central issues for the governance of a destination (Crouch and Ritchie, 1999; Dwyer and Kim, 2003) and relate directly to the attractiveness of the tourism destinations, which explains the result achieved by the destination and highlights the importance of these activities for destination competitiveness. 
All four destinations rated as Adequate received funding for Destination Management. Destination management has a central role in destination competitiveness models (Dwyer and Kim, 2003; Crouch and Ritchie, 1999; Heath, 2003) because it deals with issues such as cooperation, relationship with stakeholders, coordination of economic activities, planning, monitoring and evaluation and creation of formal channels of communication. According to Crouch and Ritchie (1999), destination management activities are important to enhance the appeal of core resources and attractors, strengthen the quality and the effectiveness of the supporting factors and to ensure that destinations are able to adapt to constraints and opportunities from the constantly changing environment. This kind of investments undertaken by more developed destinations are explained due to the greater complexity involved in their management, as well as the constant need to make improvements in order to maintain competitiveness.

Investments in Routes and Segments were detected only in destinations classified as Adequate. Such investments are related to studies and researches carried out about how best to exploit the full potential of tourism in new segments and how to aggregate value to products and attractions. These aspects are not directly discussed by Dwyer and Kim's (2003) or Ritchie and Crouch's (2010) models. The investments in Routes and Segments indicate the need to diversify tourist products and attractions so that advanced tourism destinations may keep their competitive position or even become more competitive.

These findings reinforce the perspective that destination competitiveness is multilevel, as highlighted by Esser and collaborators (1996). These results highpoints that destinations in different stages of competitiveness development demand different kinds of investments. Destinations at early stages of competitiveness seem to benefit more of investments in Infrastructure and Training \& Qualification. These investments are necessary to establish the bases for sustainable tourism development and to build capacity of the workforce employed at tourism activities. As emphasized by Crouch and Ritchie (1999), both infrastructure and training are supporting factors that provide the foundations for a successful tourism industry.

On the other hand, advanced destinations are more intensive in investments oriented to increase the general appeal of their products, diversify their attractors, build capacity for effectively competing and improve their market positioning. There seems to be stages that both define the destination and the type of investment required. Thus, in destinations with no basic infrastructure, investments in infrastructure are not only required, but also serve to qualify the destination. In destinations with existing infrastructure, destination management becomes the most relevant competitive challenge, requiring actions to promote and develop tourist attractions and products. These findings show that, in more advanced stages of development, destinations need to diversify their activities by creating new routes and exploring new tourism segments which will enable them to enhance competitiveness.

As a consequence, the importance of the different types of investments vary according to the stage of destination development, which confirms the views presented by Hassan (2000), Wilde and Cox (2008) and Cvelbar and collaborators (2016) that key variables for destination competitiveness vary according to a destination's development. These results reiterate the role played by public management on destination development. More funding does not necessarily implicate in competitiveness improvement. In order to promote development, the resources should be invested according to 
destination development level. Therefore, the need for planning and management for the development of tourism is emphasized.

\section{COMPETITIVENESS ENHANCEMENT AND JOB GENERATION}

The influence of destination competitiveness on local development was analyzed through multiple regression analysis. The variation on competitiveness dimensions were considered as independent variables and the variation on the number of employments on accommodation services were considered as dependent variables. Table 2 presents the results of regression analysis. The Model 1 tested only the competitiveness dimensions. Models 2 to 5 present the results of the regression analysis with control variables (dummies) for destination's main type of attractors and the demand characteristics.

\section{TABLE 2 REGRESSION ANALYSIS RESULTS — DEPENDENT VARIABLE EMPLOYMENT}

\begin{tabular}{|c|c|c|c|c|c|}
\hline Variables & Model 1 & Model 2 & Model 3 & Model 4 & Model 5 \\
\hline Infrastructure & 0,004 & 0,004 & $-0,002$ & $-0,002$ & 0,004 \\
\hline Access & 0,083 & 0,086 & 0,086 & 0,053 & 0,075 \\
\hline Services \& Equipment & 0,188 & 0,189 & 0,067 & 0,164 & 0,175 \\
\hline Attractions & $-0,146$ & $-0,147$ & $-0,146$ & $-0,110$ & $-0,092$ \\
\hline Marketing & 0,202 & 0,203 & $0,206^{\star}$ & $0,251^{*}$ & $0,233^{*}$ \\
\hline Public Policies & $-0,149$ & $-0,150$ & $-0,184^{*}$ & $-0,144$ & $-0,160$ \\
\hline Cooperation & $0,313^{\star *}$ & $0,312^{\star *}$ & $0,307^{\star *}$ & $0,326^{\star \star}$ & $0,301^{\star *}$ \\
\hline Monitoring & $0,254^{*}$ & $0,256^{\star}$ & $0,279^{\star \star}$ & $0,232^{*}$ & $0,248^{*}$ \\
\hline Economy & 0,030 & 0,028 & 0,073 & 0,085 & 0,017 \\
\hline Entrepreneurship & $-0,097$ & $-0,099$ & $-0,182$ & $-0,113$ & $-0,080$ \\
\hline Social Aspects & $-0,254^{\star *}$ & $-0,255^{\star \star}$ & $-0,153$ & $-0,202^{*}$ & $-0,215^{\star}$ \\
\hline Environmental Aspects & 0,016 & 0,016 & 0,010 & $-0,027$ & $-0,004$ \\
\hline Cultural Aspects & $-0,180$ & $-0,183$ & $-0,250^{\star \star}$ & $-0,175$ & $-0,188$ \\
\hline Business & - & 0,009 & - & - & - \\
\hline Cultural & - & - &,$- 335^{\star \star}$ & - & - \\
\hline Natural & - & - & - &, $240^{\star *}$ & - \\
\hline Sun and Sand & - & - & - & - & 0,129 \\
\hline R Square & 0,490 & 0,490 & 0,570 & 0,537 & 0,501 \\
\hline Adjusted R Square & 0,339 & 0,324 & 0,430 & 0,386 & 0,339 \\
\hline ANOVA Sig. & 0,002 & 0,003 & 0 & 0,001 & 0,002 \\
\hline
\end{tabular}

Source: Elaborated by the authors.

* Statistical significance at the level of 0.1 .

** Statistical significance at the level of 0.05 . 
The findings indicate that the dimensions Cooperation and Monitoring reached statistical significance at all five models tested, which indicates the importance of these dimensions for local development. According to BCM (Brazilian Ministry of Tourism, Sebrae and Fundação Getulio Vargas, 2008, 2010), the Cooperation dimension include among other aspects destination governance and support for integrated production and marketing; whilst Monitoring address issues as generation and disclosure of information on the development of the tourism economy.

Marketing had a significant result in three of the five models tested, but only for models with control variables for leisure attractions. Marketing activities are normally directed towards destination promotion, commercialization and market positioning and are an important part of destination management (Dwyer and Kim, 2003; Crouch and Ritchie, 2010). According to Bornhorst, Ritchie and Sheehan (2010), destination management organizations main is to seek to enhance the social and economic well-being of the residents by proving visitors with activities and experiences. This result associates destination marketing and promotion with the generation of positive outcomes for the local population.

Important to highlight that Cooperation, Monitoring and Marketing dimensions are directly related to destination management in Dwyer and Kim's (2003) and Ritchie and Crouch's (2010) models. These results corroborate the findings of Cvelbar and collaborators (2016) and stress the role played by destination management for competitiveness enhancement.

The dimension Social Aspects had a significant influence on the dependent variable in four of the five models tested. The standardized Beta coefficient, however, presented a negative coefficient, indicating that the independent variable has a negative influence on employment in the accommodation services sector. The same negative influence occurred with the control variable for cultural attractions. Even though tourism has been acknowledged as an economic activity with positive potential effects on income and job generation (Heath, 2003; González and Ruiz, 2006), these negative results indicate tourism's potential negative impacts, usually ignored by the literature. If not properly managed, tourism outgrowth may lead to the dismantlement of destination natural and cultural attractions (Lage and Milone, 2001).

In Brazil, the average wage of most tourism economic activities is below average, compared to other economic activities (for further information see Brazilian Institute for Applied Economic Research Ipea, 2015). In this sense, social development, specially education, may contribute to the search for jobs in other activities, with better wages resulting in a negative influence on the dependent variable. Tourism is considered an alternative for social inclusion through job generation. Be that as it may, it is worth questioning the quality of the employment created.

In the same sense, the social aspects and public policy variables showed negative Beta coefficients in the Model with a control variable for cultural attractions. Hassan (2000) argues that the connection among tourism and sustainability is obvious, since destinations depend on their unique natural and cultural resources for success. The result may indicate a possible problem in exploring cultural destinations. Although destination competitiveness is often understood as an intermediate goal towards socio-economic prosperity (Dwyer and Kim, 2003; Ritchie and Crouch, 2010; Cvelbar et al., 2016), these negative results reinforce the perspective that tourism not only generates positive outcomes, which reiterates the importance of planning and coordination for destination development (Crouch 
and Ritchie, 1999; Dwyer and Kim, 2003). It is up to governments to organize public policies that maximize tourism positive returns (Lage and Milone, 2001).

Differently from the results obtained by Cvelbar and collaborators (2016), the dimensions associated with destination resources, such as Infrastructure, Access, Services and Equipment and Attractions, as well as with business environment, such as Economy and Entrepreneurship, did not present significant results for the models tested. Natural resources and cultural heritage are destinations' innate and idiosyncratic aspects that should be explored in order to become more attractive for customers (Hassan, 2000). Even though natural and cultural resources are usually rare, valuable, and difficult to imitate - characteristics of a strategical resources (Barney, 1991) - Crouch and Ritchie (1999) highlight that these components relate to destination's comparative advantages that ought to be developed in order to produce positive outcomes for destination competitiveness and for local development. Natural and cultural resources, although important, are not sufficient for destination competitiveness (Cracolici and Nijkamp, 2008).

It might be observed from the regression coefficients that the statistical significance of independent variables varies according to the controlled variables. Especially for destinations with leisure attractions. These results indicate that the competitiveness determinants vary according to the characteristics of the studied destinations. The main destination competitiveness models (Crouch and Ritchie, 1999; Dwyer and Kim, 2003; Heath, 2003; Ritchie and Crouch, 2010; WEF, 2015) sought to assess competitiveness in tourism destinations broadly, regardless of their supply or demand characteristics. The results allow us to question the validity of the unrestricted comparisons derived from comprehensive models.

\section{CONCLUSIONS}

This study sought to analyze the efficiency of federal government funding for competitiveness development in Brazilian destinations and to analyze the effects of competitiveness enhancement on local socio-economic development. DEA analysis was used to identify efficient destinations in improving competitiveness. These destinations ' patterns of investment indicate that the relationship between investments and competitiveness does not depend on the amount of resources invested, but on the strategic guidance used in their application. Less developed destinations demand investments in support resources, as infrastructure, in order to add value to their endowed resources. Developed destinations, on the other hand, depend more on resources related to destination management, strategic market positioning and on diversifying tourist attractions. The results indicate that the investments should be undertaken accordingly to destination's stage of development, which stresses the role played by destination management, especially public tourism management organizations, in identifying and orienting investments.

The analysis of competitiveness influence on local development demonstrated that competitiveness determinants vary according to the characteristics of the attractions offered. The positive influence of Cooperation, Marketing and Monitoring dimensions on employment support the idea that the destination management is determinant for the generation of positive outcomes for the local population. The prominence of management for tourism success may well explain why some destinations, even when endowed with rich natural and cultural resources, are unable to develop tourism. This seems to be an important contribution from the present study, since few studies about 
destination competitiveness address special considerations on how the different dimensions affects tourism development. Still considering the main destination competitiveness models developed, this study advances on the discussion about the relative importance of the attributes of destination competitiveness.

This study has its limitations. The investments in the destinations consider only data from the Ministry of Tourism, disregarding other public (state and local governments) or private sources, also important for tourism development. The study of the impacts of other investments from other public authorities as well as private investments is a possible point for future research. Multiple regression analysis was undertaken with a diminished number of cases, which might affect the significance of the results. We used a single variable - employment on accommodation services - for local development assessment, which is another limitation. Even though this variable was supported by the literature, it represents a reductionist perspective for the construct. Future research ought to consider testing a broader set of variables in order to better represent local development. 


\section{REFERENCES}

ANDRÉ, María E. Políticas locales de dinamización turística y grandes atractivos culturales: el caso de Figures. In: SENTIAS, Josep F. Casos de Turismo cultural: de la planificación estratégica a la gestión del producto. Barcelona: Ariel, 2004.

ÂNGULO MEZA, Lídia et al. Siad - Sistema Integrado de Apoio à Decisão. In: REUNIÃO REGIONAL DA SOCIEDADE BRASILEIRA DE PESQUISA OPERACIONAL, 1., 2003, Rio de Janeiro. Anais... Rio de Janeiro: Erpo, 2003.

BARBOSA, Luiz G. M.; OLIVEIRA, Carlyle T. F; REZENDE, Cristiane. Competitiveness of tourist destinations: the study of 65 key destinations for the development of regional tourism. Rev. Adm. Pública, Rio de Janeiro, v. 44, n. 5, p. 1067-1095, Sept./Oct. 2010.

BARNEY, Jay B. Firm resources and sustained competitive advantage. Journal of Management, v. 17, p. 99-120, 1991.

BARROS, Carlos P. Measuring efficiency in the hotel sector. Annals of Tourism Research, v. 32, n. 2, p. 456-477, 2005.

BONET, Lluís. La estrategia de turismo de Barcelona, un consorcio público-privado de éxito. In: SENTIAS, Josep F. Casos de turismo cultural: de la planificación estratégica a la gestión del producto. Barcelona: Ariel, 2004.

BORNHORST, Tom; RITCHIE, J. R. Brent; SHEEHAN, Lorn. Determinants of tourism success for DMOs \& destinations: an empirical examination of stakeholders' perspectives. Tourism Management, v. 31, n. 5, p. 572-589, 2010.

BRAZILIAN MINISTRY OF TOURISM; SEBRAE; FUNDAÇÃO GETULIO VARGAS. Estudo de competitividade dos 65 destinos indutores do desenvolvimento turístico regional - relatório Brasil. 2008. Available at: <http://dadosefatos.turismo.gov. br/indice-de-competitividade-do-turismo-nacional. html>. Accessed on: 1 June 2016.

BRAZILIAN MINISTRY OF TOURISM; SEBRAE; FUNDAÇÃO GETULIO VARGAS. Estudo de competitividade dos 65 destinos indutores do desenvolvimento turístico regional - relatório Brasil. Brasília - DF, Brazil, 2010. Available at: $<$ http://dadosefatos.turismo.gov.br/indice-de- competitividade-do-turismo-nacional.html >. Accessed on: 1 June 2016.

BUHALIS, Dimitrios. Marketing the competitive destination of the future. Tourism Management, v. 21, n. 1, p. 97-116, 2000.

CASTRILlÓn, María I. D. et al. Análisis de los principales modelos explicativos de la competitividad de los destinos turísticos en el marco de la sostentabilidad. Revista Cultura y Turismo, a. 5, n. 2, p. 101-124, 2011.

CRACOLICI, María F.; NIJKAMP, Peter. The attractiveness and competitiveness of tourist destinations: a study of Southern Italian regions. Tourism Management, v. 30, n. 3, p. 336-344, 2008.

CROUCH, Geoffrey I. Destination competitiveness: an analysis of determinant attributes. Journal of Travel Research, v. 50, n. 1, p. 27-45, 2011.

CROUCH, Geoffrey I.; RITCHIE, J. R. Brent. Tourism, competitiveness, and societal prosperity. Journal of Business Research, v. 44, n. 3, p. 137-152, 1999.

CRUMPTON, Charles D. et al. Avaliação de políticas públicas no Brasil e nos Estados Unidos: análise da pesquisa nos últimos 10 anos. Rev. Adm. Pública, Rio de Janeiro, v. 50, n. 6, p. 981-1001, Nov./Dec. 2016.

CZERNEK, Katarzyna; CZARON, Wojciech. Trustbuilding processes in tourist coopetition: The case of a Polish region. Tourism Management, v. 52, p. 380-394, 2016.

CVELBAR, Ljubica K. et al. Drivers of destination competitiveness in tourism: a global investigation. Journal of Travel Research, v. 55, n. 8, p. 1041-1050, 2016.

DENICOLAI, Stefano; CIOCCARELLI, Gabriele; ZUCHELLA, Antonella. Resource-based local development and networked core-competencies for tourism excellence. Tourism Management, v. 31, p. 260-266, 2010.

DWYER, Larry; KIM, Chulwon. Destination competitiveness: determinants and indicators. Current Issues in Tourism, v. 6, n. 5, p. 369-414, 2003.

ENRIGHT, Michael J.; NEWTON, James. Tourism destination competitiveness: a quantitative approach. Tourism Management, v. 25, n. 6, p. 777-788, 2004. 
ESSER, Klaus et al. Competitividad sistémica: nuevo desafío a las empresas y a la política. Revista de la Cepal, n. 59, p. 39-52, 1996.

GONZÁLEZ, María B.; RUIZ, David F. La competitividad internacional de los destinos turísticos: del enfoque macroeconómico al enfoque estratégico. Cuadernos de Turismo, n. 17, p. 7-24, 2006.

GOOROOCHURN, Nishaal; SUGIYARTO, Guntur. Measuring Competitiveness in the travel and tourism industry. Discussion Paper - TTRI. Nottingham: University of Nottingham, 2004.

HASSAN, Salah S. Determinants of market competitiveness in an environmentally sustainable tourism industry. Journal of Travel Research, v. 38, n. 3, p. 239-245, 2000.

HEATH, Ernie. Towards a model to enhance destination competitiveness: a Southern African perspective. Journal of Hospitality and Tourism Management, v. 10, n. 2, p. 124-141, 2003.

INSTITUTO BRASILEIRO DE GEOGRAFIA E ESTATÍSTICA (IBGE). Economia do turismo: uma perspective macroeconômica 2000-2005. Estudose Pesquisas Informação Econômica, n. 7, Rio de Janeiro, 2008. Available at: <http://dadosefatos.turismo. gov.br/images/pdf/outros_estudos/economia_do_ turismo/estudo_economia_do_turismo__uma_ perpectiva_macroeconomica__2000_2005.pdf > . Accessed on: 1 June 2016.

INSTITUTO DE PESQUISA ECONÔMICA APLICADA (IPEA). Relatório com as estimativas da caracterização da ocupação formal e informal do turismo. 2015. Available at: <www.ipea.gov.br/ portal/images/stories/PDFs/150317_estimativas_ ocupacao-2015.pdf>. Accessed on: 1 June 2016.

LAGE, Beatriz H. G.; MILONE, Paulo C. Economia do turismo. 7. ed. São Paulo: Atlas, 2001.

MAGGIONI, Isabella; MARCOZ, Elena M.; MAURI, Chiara. Segmenting networking orientation in the hospitality industry: an empirical research on service bundling. International Journal of Hospitality Management, v. 42, p. 192-201, 2014.

MAZARO, Rosana M.; VARZIN, Giovani. Modelos de competitividad para destinos turísticos en el marco de la sostenibilidad. Rev. de Adm. Contemporânea, Curitiba, v. 12, n. 3, p. 789-809, 2008.
MEDINA, Lilibeth F.; GÓMEZ, Ignacio G.; MARRERO, Sandra M. Measuring efficiency of sun \& beach tourism destinations. Annals of Tourism Research, v. 39, n. 2, p. 1248-1251, 2012.

MICHAEL, Ewen J. Micro-clusters and networks: the growth of tourism. New York: Elsevier, 2007.

MIKI, Adriana F. C.; GÂNDARA, José M. G.; MUÑOZ, Diego R. M. O estado atual das pesquisas sobre competitividade turística no Brasil. Caderno Virtual de Turismo, v. 12, n. 2, p. 212-223, 2012.

NUÑEZ, Fernanda R. Benchmarking the competitiveness of Brazilian cities. In: ZHANG, Ming (Org.). Competitiveness and growth in Brazilian cities: local policies and actions for innovation. Washington, DC: World Bank, p. 93-106, 2010.

PAVLOVICH, Kathryn. The evolution and transformation of a tourism destination network: the Waitomo Caves, New Zealand. Tourism Management, v. 24, n. 2, p. 203-216, 2003.

PIKE, Steven; PAGE, Stephen J. Destination marketing organizations and destination marketing: a narrative analysis of the literature. Tourism Management, v. 41, p. 202-227, 2014.

PORTER, Michael. Estratégia competitiva. São Paulo: Campus, 1986.

RAMOS, Marília P.; SCHABBACH, Letícia M. O estado da arte da avaliação de políticas públicas: conceituação e exemplos de avaliação no Brasil. Rev. Adm. Pública, Rio de Janeiro, v. 46, n. 5, p. 1271-294, Sept./Oct. 2012.

RITCHIE, J. R. Brent; CROUCH, Geoffrey I. A Model of destination competitiveness/sustainability: Brazilian perspectives. Rev. Adm. Pública, Rio de Janeiro, v. 44, n. 5, p. 1049-66, Sept./Oct. 2010.

RIVERO, Marcelino S.; CALDERA, Miguel A. F. La competitividad de los destinos turísticos: un análisis cuantitativo mediante modelos logísticos - aplicación a los municipios extremeños. In: JORNADA DE ECONOMÍA DEL TURISMO, 1., 2004, Mallorca. Proceedings... Mallorca: Aecit, 2004. p. 1-21.

SINCLAIR, M. Thea; STABLER, Mike. Aspectos econômicos do turismo. Brasília: Universidade de Brasília, 2009. 
TABERNER, Jaume G. Propuesta de dos índices para la medición de la competitividad de los destinos de sol y playa del Mediterráneo. Revista de Análisis Turístico, n. 4, p. 50-67, 2007.

TREVISAN, Andrei P.; VAN BELLEN, Hans M. Avaliação de políticas públicas: uma revisão teórica de um campo em construção. Rev. Adm. Pública, Rio de Janeiro, v. 42, n. 3, p. 529-550, 2008.

TRIMARCHI, Michele. Distritos culturales y desarrollo económico del territorio: la experiencia de los museos de Siena. In: SENTIAS, Josep F. Casos de turismo cultural: de la planificación estratégica a la gestión del producto. Barcelona: Ariel, p. 109124, 2004.
WILDE, Simon J.; COX, Carmen. Linking destination competitiveness and destination development: findings from a mature Australian tourism destination. In: EUROPEAN CHAPTER CONFERENCE - COMPETITION IN TOURISM: BUSINESS AND DESTINATION PERSPECTIVES, 2008, Helsinki. Proceedings... Helsinki: TTRA, 2008. p. 467-478 Available at: <https://epubs.scu.edu.au/ cgi/viewcontent.cgi? article $=1009 \&$ context $=$ comm pubs>. Accessed on: 1 Feb. 2014.

WORLD ECONOMIC FORUM (WEF). The travel and tourism competitiveness report 2015. Geneva, Switzerland, 2015. Available at: <www3.weforum. org/docs/TT15/WEF_Global_Travel\&Tourism_ Report_2015.pdf>. Accessed on: 1 Nov. 2015.

\section{Daniel Pires Vieira}

PhD in Business Administration at University of Brasília (UnB), Brazil. E-mail: vieira.pires@gmail.com.

Valmir Emil Hoffmann

$\mathrm{PhD}$ in Business Administration at University of Zaragoza, Spain. E-mail: ehoffmann@unb.br.

\section{Anete Alberton}

PhD in Production Engineering at University of Santa Catarina (UFSC), Brazil. E-mail: anete@univali.br. 